\title{
Dialogic Speech in Marriage Proposal of Konjonese
}

\author{
Harlinah Sahib ${ }^{1 *}$, Fathu Rahman ${ }^{2}$ \\ 1,2 English Department Faculty of Cultural Sciences Hasanuddin University \\ * Corresponding author. Email: harlina.sahib@unhas.ac.id
}

\begin{abstract}
This research is entitled Dialogic Speech in Marriage Proposal of Konjonese. The objectives of this research are 1). To describe the procedure of marriage proposal of Konjonese. 2).To disclose the features of the dialogic speech in the marriage proposal. The qualitative method was used in obtaining the data of marriage proposals. In addition, the researcher herself had a role as a key instrument which has to master the field being researched and the preparation to come to the object of the research. Ammatoa, the head of the community is the main important source of information in a variety of aspects such as customary ritual, kinship, religious beliefs and family organization, and marriage proposal as well. The data of marriage proposals were gained through some techniques: observation, recording, interview, and note-taking. Whereas the result of the research shows that the marriage proposal of Konjoneseis usually performed in the form of dialogic speech by three important people.
\end{abstract}

Keywords: dialogic speech, marriage, proposal, konjonese

\section{INTRODUCTION}

The term of the marriage proposal, a delightful event is very longed for by all people, youth and adult people. It is either a traditional or modern wedding. This kind of event is usually conducted before the time of the wedding. However, several important points should be considered by both sides, man's and woman's family. They are the ways of proposing marriage and language features used is usually different from one place to another. This difference can be caused by tradition that exists in one ethnicity. Since every tradition has its ways and language features in a marriage proposal, people who are involved in the event should arrange the procedure of proposing and language features that the man's delegation uses as very often marriage proposal is unsuccessful because of trivial matter. Therefore, either the young man's delegation or the young woman's family should have a mutual understanding of the marriage proposal.

This research was conducted in ethnic Kajang who speaks bahasa Konjo, at the eastern part of Bulukumba regency in which this ethnic was established as the object and place of researching since this ethnic keeps maintaining its strong tradition either in wedding and other lifecycles. One of the strengths of doing this kind of unique tradition is caused by its ancestors' messages (instruction) called Pasang ri Kajang which contains the command, prohibition, and offer. This informal knowledge had been embedded in its psyche and thought, therefore it is considered its ways of life.

Proposing young women for Konjonese especially ethnic Kajang has an individual problem as the man's family may not contact directly to woman's parents or they may not present at marriage proposal event. This ethnic believes that the presence of a woman's parents is regarded as taboo or because of tradition. Yet, no people can violate this tradition as it was suggested and instructed in its traditional message which is continuously carried out from one generation to the next. As is suggested by [1] Pasang (traditional message of Kajang) is a guideline, and reference in carrying out its various aspects of life. In addition, Usop, [2] statedPasang ri Kajang contains all knowledge and experience of all aspects of human's lives which were messaged by their ancestors from one generation to the next. This message is obliged to be obeyed and carried out by its community. In other words, this message can result in a negative impact on the community if it is not implemented in their daily lives. In short, this traditional message conveys all traditional or local knowledge of people. Another idea about Pasang is advice, guidance, and instruction originated from 
God (Tu riek Akrakna) which was expressed by first human in the world (tu mariolo).

\subsection{The Procedure of Marriage Proposal of Konjonese}

Likewise other ethnics, Konjonese in this case ethnic Kajang preeceds marriage proposal by sending female delegation called akbisik-bisik (to wishper) to ask if or whether the daughter of one family has not been proposed by a man. This whispering (akbisik-bisik) is extended to wised woman's uncle or grandparents from her father's family line.

Then the woman's relative (uncle)extends the whispering to the woman's parents. When the woman's parents know about the good news, the woman's uncle under the suggestions of the woman's parents goes to meet Ammatoa and his assistants to extend them the plan. Next, the application is not immediately accepted by the head of the community but he usually invites his assistants to clarify if the family never made any mistakes before. If he has (such as cutting woods without permitting to customary) he will then be asked to pay the fine that he has made before. In other words, they will not be responded to before he has completed paying the fine. Furthermore, Ammatoa decides which assistants will present at that event. Yet, for this kind of event, Ammatoa usually points GalakPutok to represent him. After the plan or purposes of the woman's relatives responding by Ammatoa, the woman's family will look for the appropriate time to conduct the marriage proposal. In addition, at the time decided the woman's relatives, customaries, man's delegation (suro), and honoured man (batubatupakrasangeng) present to woman's house. The three people and the woman's parents sit together and chit chat while drinking and eating some cookies and then continue with having dinner together. After having dinner, batu-batu pakrasangeng (an honoured man) usually begins the talk until reach an agreement.

\subsection{The Performance of Marriage Proposal In Konjonese}

Principally, there are only three people who have the main function in performing the marriage proposal of Konjonese Gallak Putok, Batu-batu pakrasangeng, and Suro. Yet, there are usually other people involved in that event. Although there are four steps followed by speech uttered in the proposal event, only three people take apart or speak in the marriage proposal. They are batu-batu pakrrasangeng (an honoured man), Gallak Putok (the secretary of Ammatoa), and Suro (man's delegation). The first dialogue is usually performed by Gallak Putok on behalf of customary. He usually begins the talk as an attention giver that that kind of work is not at random one but serious work. That work will impact family disappointment if that work will not be realized. As we can hear Gallak Putok's speech inni bangngia apa akkattanu? "What's your purpose to come this evening?"

When the requirements of a woman's family are responded to or agreed upon by the man's delegation and the man's family, they will then agree with the man's family or delegation to come again and to extend to woman's family about the requirements or what has been agreed together. The second speaker is usually performed by Batu-batu pakrasangeng (an honoured man) whose functions as a mediator between man's family and woman's family. He extends that rua sipallapikang apa na padongkok ri sallang riek lalanna sikanakkuki pappolong parrukang "two things are sent by the man's family, not a wealth, not a proud but homesickness or brotherhoods' love".

The last speaker is suro (man's delegation) at the time of the marriage proposal. Suro has a very important role in the event of a marriage proposal as he is the only one known by customary and woman's family about the marriage proposal. From him, a woman's family, customary, and public will know that young woman will marry. What a shameful of woman's family and public if a sacred event will not be conducted because of trivial matter. Here is the suro's example of the dialogic deduction sallannanjo mae ammanna i Sangkala, lekleng rua buleng sikaju "Sangkala's parents regret to all with two buffalloes, one farmland or ricefield and some money, napattanjengang " is witnessed to the secretary of Ammatowa and continued it to Ammatowa. After the dialogue finished Gallak Putok closes the speech and asks the suro to come and bring the requirements agreed together.

\section{FEATURES OF DIALOGIC SPEECH IN MARRIAGE PROPOSAL OF KONJONESE}

As mentioned before, the dialogic speech of Konjonese is usually uttered by three people and each person has a different speech from the other. Besides, the dialogic speech of marriage proposal of Konjonese usually uses higher and formal language as we can see the opening speech done by Gallak Putok: maingki angnginung tua, anganre lahara, coba allo panynyangkoang, a'ra'a paka' batu pammole samajaang. inni bangngia apa akkattanu?" Galla' Puto, at the moment we have drunk palm win, eat a slice of fish, if it is the time of cultivating farm I wish a very strong stone (wish) as a payment of promise by the way, what is your purpose to come this evening?" 
The next dialogic speech is conducted by Batubatu pakrasangeng (an honoured man) as the second speaker. rua sipallapikang apa na padongkok ri sallang, talia kariekang, talia kaakrakkang niarek, kaminang konjona, riek lalanna sikanakkuki, pappolong parrukang, silampa-lampai bahine para bahine, silampalampai toi burukne para burukne, iaji pau ri bahinea, lettek tampe ri buruknea apai nabalabala, lekleng rua buleng sikaju, realasitaiknapattanjengang ri pukgallaktulusuk ri Ammatoa. "two kinds ofthings are going to bring, it is not wealth, it is not an obstinacy, but the most important point is a longing for each other, fraternity or friendship, visiting female and the same gender as well as male and the same group, move to the male's place. What something wished is two buffaloes, one farmland or ricefield, extended to the secretary of Ammatoa (the secretary of the community) as well as to Ammatoa".

The third dialogic speech is reextended by Gallak Putok (Ammatoa's Secretary) batu-batu pakrasangeng, suroi appau suroa, punna akpaui suroa, napau tappai ada'a. Rua tanna pattojek, ri dallekanna pangadakkanga makase're pangitte ahuk-ahuk, makarua pallangngere salimpajo,"An honored man, asked GallakPutok, ask the delegation or Suroto extend their wishes if the delegation (suro) extend their wishes they will be trusted by the customary apparatus. Two things that can not be accepted in the customary. The first thing is the only vague view (words without evidence) and the second is unclear hearing only (news but not true words)".

The last is the speech expressed by the man's delegation (suro): here is their speech tabepukgallak,batu-batupakrasangeng, sallannanjo mae tutoana i Sangkala riek lalonna sikanakkuki, bahine para bahine, burukne para burukne napassibulo-bulo inni riburuknea. Apai napadongko risallang lekleng rua buleng sikaju realasitaiknapattanjengang ri puk gallak tulusu mange ri Ammatoa. 'Sangkala's father sends regards to all of you. There is a longing for each other (fraternity and friendship) visiting also female and the same gender as well as the male and the same group. What something wished is two buffaloes, one farmland or ricefield, extended to the secretary of Ammatoa (the leader of the community) as well as to Ammatoa".

In addition, those speeches or expressions are parallel as seen in the pharases silampa-lampai, bahine para bahine, burukne para burukne, pangngitte ahu-ahu', pallangngere salimpajo and metaphors as can be seen in the phrases pappolong parrukang " fraternity", lekleng rua buleng sikaju " two buffalloes, one farmland or ricefield and some money, napattanjengang " is witnessed to the secretary of Ammatowa and continued it to Ammatowa.

\section{THEORIES OF CUSTOMARY RITUAL AND DIALOGIC SPEECH IN MARRIAGE PROPOSAL OF KONJONESE}

A customary ritual such as marriage in Konjoneseis usually addressed in the form of the high register which is usually very formal, parallelisms, and metaphors. In other words, this ethnicity uses poetic language for the ritual event which is prevalent around the world and utilized differently for different purposes. This is in line with what is suggested by (Abu Lughod 1988) in Sandarupa [3] that in Indonesian society, poetry is used in rituals such as wedding and death rituals, formal, and occasions as well as in daily conversation. Bulukumba regency particularly those who live in the eastern part, uses Konjo languge (bahasa Konjo) which is used in two registers; basa allo-allo (ordinary language) and basa tinggi (high register language) is mostly contained in the Pasang ri Kajang and used it in ritual. In short, this high register is more formal in its usage and conveys deep senses. Fox [4] also suggests that ritual language in the eastern part of Indonesia contains a lot of parallelism in traditional communication.

Customary ritual has a close connection with dialogic speech and the concept of dialogue is strongly suggested by Bakhtin. Dialogue is primarily a basic model of language as discursive communication [5]. A sequence of utterances is a dialogue of speaking subjects or voices that respond to former utterances and anticipates the future ones. According to him (1986) three important factors are determining an utterance. Firstly, the content with its object and meaning (a theme being an objective factor and an authorial concept a subjective factor). Secondly, constitutive for an utterance-that is the expressiveness, the emotional - axiological relation of the speaker toward the content that could never be neutral. Thirdly, determining an utterance concerns the relationship of the speakers with the others and his utterances, the existing and the anticipated ones.

To the dialogue speech of marriage proposal, this research borrowed Bakhtin's ideas of dialogism [6]; [7]. He believes that in a dialogue, a person clearly announces that he or she does not merge with other people. In other words, people involved in the dialogue concentrate on a certain topic. It can be inferred that what dialogue speech of Bakhtin means a person does not merge with other people maybe every person has his or her ideas or concept about what they are going to say. 
Bakhtin [7] further asserted that utterance is the real unit of speech communication. This argument is a close relationship between langue and parole. Langue is the abstract quality of language (social) and parole is a more concrete use of language (individual). In addition, Bakhtin also claimed that dialogue produces genres such as informative, entertaining, demonstrative, and oratorical genres. From this, he classified genres through primary and secondary genres. Primary genres are those of everyday conversation, from the single-word rejoinder '(81) greetings, farewells, congratulations, intimate conversation among friends and within the family. Meanwhile, the secondary genre of complex genre developed in highly organized cultural communication and are usually mediated (written) removed from the context of actual reality. This type of genre is quite close to the discussion of the marriage proposal of Konjonese since this research discusses the language and culture or tradition of one ethnic.

As has been mentioned before, three important people have important roles in marriage proposal performance. Batu-batu pakrasangeng (an honoured man) usually acts as the first speaker in that event. Apart from an honoured man, Gallak Putok (the secretary of a leader of the community) is the third speaker who asserts that to propose a wished woman is not only saying something but the primarily important thing is doing something for example, pangitte ahu'-ahu', pallangngere salimpajo in the form of responsibility and facts that will be expected from the man's family. The statement of saying something and doing something uttered by Gallak Putok is relevant with Austin's Performative acts [8]. Another important person who has a key role in a marriage proposal is Suro ( people who have a close relation to the young man's parents). These delegations have to extend the man's parents purpose to marry the young woman. In this event, the man's delegation or suro has a very big responsibility or burden as they have to be responsible to the man's and woman's family. the accomplishment of the marriage event depends on the suro's effort. Therefore, becoming a marriage proposal delegation is not an easy thing.

\section{APPROACHES IN MARRIAGE PROPOSAL OF KONJONESE}

One main problem that exists within the approach of indexical mediation is the balance between text and context, Silverstein Bauman and Briggs [9] have fruitfully inferred this by quoting Blackburn and Limon, and Young suggestion. For Blackburn, performance studies are too much concerned with context and two little focus on the text. Meanwhile, Limon and Young as well as Broner argued that performance approaches are too caught up in poetics to be able to discern broader social and political context [10].

The data of marriage proposals have selected the interconnectedness between text and context. Next, Speaking encompassed reciting or expressing poetic language in wedding performance signals or refer the spatial, temporal, or causal of another [9]. This approach was started with textual data or textual analysis of the language used in the marriage proposal. The theory of Semiotics has been developed by Silverstein [9].

To the dialogic speech of the marriage proposal of Konjonesse, it seems that Batu-batu pakrasangang speech is to share information about the purpose of the delegations to come to extend the man's parents longing (wishes) to unite man and woman in a marriage celebration.

Regarding the speech genre of gallak Putok, it seems that his speech is more related to assertion, responsibility, entertainment, and rules. In addition speech genre of suro is more relevant with a commitment and promise. Such as lekleng rua, buleng sikaju napattanjengang ri puk Gallak." two buffaloes, farmland or ricefield and some money are things committed by woman's and man's family.in other words, dialogic speech 1 voices the social group of public figures, Next, dialogic speech no2 voices the social group of government (traditional government), meanwhile, dialogic speech in no 3 tends to voice social group of representers.

Primary genres are those of everyday conversation, from the single-word rejoinder '(81) greetings, farewells, congratulations, intimate conversation among friends and within the family. Meanwhile, the secondary genre of complex genre developed in highly organized cultural communication and are usually mediated (written) removed from the context of actual reality. This type of genre is quite close to the discussion of the marriage proposal of Konjonese since this research discusses the language and culture or tradition of one ethnic.

\section{RESEARCH METHODS}

The qualitative method in the form of ethnography was used in gaining the data of the marriage proposal. It means that this type of method avoids numbers, deals with interpreting, social realities. Next, Ammatoa, the head of the community and his assistants are further the main important sources of information in a variety of aspects such as customary ritual, kinship, religious beliefs and family organization, and marriage proposal as well. In addition, the researcher herself had a role as a key instrument which has to master the field being researched and the preparation to come to the object of the research. The data of the 
marriage proposal were gained through the techniques of observation, recording, interview, and note-taking. Obtaining data through observation is rather different from interviewing and questionnaires since the observation technique have more specific as it should not interact only with people but also natural objects.

\section{FINDINGS AND DISCUSSIONS}

In the marriage proposal of Konjonese, three important people make a dialogic speech and each person has a different function in that event. Gallak Putok has function as a customary apparatus, Batubatu pakrasangeng as an honourable man in the village, and Suro as the man's delegation. Gallak Putok is an opening speaker usually opens the speech by using genre of jokes such as; maingki anginung tuak, angnganre lahara. coba allo panynyangkoang a'ra'a paka' batu pammole samaja. As a customary apparatus Gallak Putok has also the power to ask inni bangngia apa akkattanu "what is your purpose to come this evening?.and this kind of sentence is not uttered by any people except a person who has authority in the formal situation.

Batu-batu pakrasangeng (an honoured man) as the second speaker uses informative genre to say rua sipallapikang apa na padongkok ri sallang, talia kariekang, talia kaakrakkang niarek, kaminang konjona, riek lalanna sikanakkuki, pappolong parrukang, silampa-lampai bahine para bahine, silampa-lampai toi burukne para burukne, iaji pau ri bahinea, lettek tampe ri buruknea apai nabala-bala, lekleng rua buleng sikaju, reala sitaik napattanjengang ri pukgallak tulusuk ri Ammatoa. "two kinds of things are going to bring, it is not wealth, it is not an obstinacy, but the most important point is a longing for each other, fraternity or friendship, visiting female and the same gender as well as male and the same group, move to the male's place. What something wished is two buffalloes, one farmland or ricefield, extended to the secretary of Ammatoa (the secretary of community) as well as to Ammatoa".

In addition, Gallak Putok (Ammatoa's Secretary) uses his power which may not be uttered by any person informal situation by saying to batubatu pakrasangeng, suroi appau suroa, punna akpaui suroa, napau tappai ada'a. Rua tanna pattojek, ri dallekanna pangadakkanga makase're pangitte ahuk-ahuk, makarua pallangngere salimpajo,"An honored man, asked GallakPutok, ask the delegation or Suroto extend their wishes if the delegation (suro) extend their wishes they will be trusted by the customary apparatus. Two things that can not be accepted in the customary. The first thing is the only vague view (words without evidence) and the second is unclear hearing only (news but not true words)".
In addition to Gallak Putok and Batu-batu pakrasangeng, man's delegation (suro) extends genres of expectation such as tabe pukgallak,batubatu pakrasangeng, sallannanjo mae tutoana $i$ Sangkala riek lalonna sikanakkuki, bahine para bahine, burukne para burukne napassibulo-bulo inni riburuknea. Apai napadongko risallang lekleng rua buleng sikaju reala sitaik napattanjengang ri puk gallak tulusu mange ri Ammatoa. "Sangkala's father sends regards to all of you. There is a longing for each other (fraternity and friendship) visiting also female and the same gender as well as the male and the same group. What something wished is two buffaloes, one farmland or ricefield, extended to the secretary of Ammatoa (the leader of the community) as well as to Ammatoa".

In addition, this dialogue contains the denotational and interactional text. Denotational text can be seen in the form of parallelism, metonym, and metaphor. Parallel style of language is mostly found in the text of ritual in ethnic Kajang such as; wedding and death ritual. In marriage, proposal parallelism is also found in the sentence of anginung tuak, anganre lahara. pangitte ahu'-ahu', pallangngere saling pajo. bahine para bahine, burukne para burukne. Lekleng rua, buleng sikaju. Apart from parallelism, the text of the marriage proposal has also metonym such as lekleng rua, buleng sikaju. Lekleng rua buleng sikaju means black colour buffaloes, and buleng sikaju means gold or farmland. Different from parallelism and metonyms, the text of marriage proposal in Konjonese also contains metaphors for example pangitte ahu'-ahu', pallangngere saling pajo is similar to say not true (only saying but realization). Interactional text on the other hand is related to indexicality such as deixsis of time such as inni bangngia (this evening), inni (this) $r i$ (in) as a deixis of place. In addition this text of marriage proposal develop social relations of longing for uniting two big families, and the evidence of the longing is realized in the forrm of goods such as lekleng rua, buleng sikaju, reala sitaik "buffaloes, farmland and gold, and money.

\section{CONCLUSION}

Marriage proposal in Konjonese is a kind of lifecycles that is usually conducted before a wedding. In the event of the marriage proposal, three important people have the main function, they are customary apparatus, an honoured man in the village called batu-batu pakrasangeng, and suro or man's delegation. In addition, there two important things were discussed in this research the procedure of marriage proposal and the features or the characteristics of the text or dialogic speech of marriage proposal of Konjonese. 


\section{BIBLIOGRAPHY}

[1] Sahib. Harlinah. 2017. Entextualization and Genre Transformation of Jang Death Ritual Speech. Dissertation. Hasanuddin University. Unpublished.

[2] Usop, M.1978. PasangriKajang: KajianSistemNilai di BentengHitam. Ammatowa. Ujung Pandang. Ujung Pandang: Laporan Penelitian Pusat Latihan PenelitianIlmu- Ilmusosial.

[3] Sandarupa, Stanislaus. 2004. The Voice of a Child: Constructing the moral society through the retteng poetic argumentation in toraja, Sulawesi, Indonesia. This paper present in the

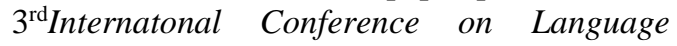
Education 2013 at Makassar Phinisi UNM Makassar on 6-7 Desember 2013.

[4] Fox, James. J. 1988. To Speak in Pairs (Essay on the Ritual Language of Eastern Indonesia. Cambridge University Press.

[5] Bakhtin, M. M. (2001). Philosophy of Mikhail Bakhtin: The Concept of Dialogism and Mystical Thought [1].

[6] Bakhtin, M. M. 1981. Dialogic Imagination: Four Essays, Ed. Michael Holquist. Trans. Caryl Emerson and Michael Holquist. University of Texas Press. Austin, 1981

[7] Bakhtin, M. M. 1986. The Problemof Speech Genres. In Speech Genres andOther Late essays. C.E.a.M Holquist. Ed. Pp.60-102. Austin: University of Texas Press.

[8] Austin, J.L. 1962. How to Do Thing with Words. Cambridge. Mass: Harvard University Press.

[9] Sylverstein, Michael. 1984.On the Pragmatic Poetry of 'Prose': Parallelism, Repetition, and Cohesive Structure in the Real Tie Course of Dyadic Conversation. In Meaning, form, use in contex: linguisticapplications. D. Schiffrin. Ed.

[10] Briggs, Charles L, and Richard Bauman. 1992. Genre, Intertextuality, andSocial power. Linguistic Anthroplolgy 2 (2): 131-172. 